\title{
SEROPREVALENCE OF ANTI-SARS-COV-2 ANTIBODIES IN THE NORTHERN ITALY POPULATION BEFORE THE COVID-19 SECOND WAVE
}

\author{
NAUSICAA BERSELLI ${ }^{1}$, TOMMASO FILIPPINI ${ }^{1}$, STEFANIA PADUANO ${ }^{1}$, MARCELLA MALAVOLTI ${ }^{1}$, \\ ALBERTO MODENESE ${ }^{1}$, FABRIZIOMARIA GOBBA ${ }^{1}$, PAOLA BORELLA ${ }^{1}$, ISABELLA MARCHESI ${ }^{1}$, \\ ROBERTO VIVOLI ${ }^{2}$, PAOLA PERLINI ${ }^{2}$, ROSSANA BELLUCCI ${ }^{2}$, ANNALISA BARGELLINI ${ }^{1 *}$, and MARCO VINCETI ${ }^{1,3 *}$
}

${ }^{1}$ University of Modena and Reggio Emilia, Modena, Italy

Department of Biomedical, Metabolic and Neural Sciences

${ }^{2}$ Test Laboratory, Modena, Italy

${ }^{3}$ Boston University School of Public Health, Boston, Massachusetts, USA

Department of Epidemiology

\begin{abstract}
Objectives: The COVID-19 pandemic is due to SARS-CoV-2 coronavirus infections. It swept across the world in the spring of 2020, and so far it has caused a huge number of hospitalizations and deaths. In the present study, the authors investigated serum anti-SARS-CoV-2 antibody prevalence in the period of June 1-September 25, 2020, in 7561 subjects in Modena, Northern Italy. Material and Methods: The study population included 5454 workers referred to testing by their companies, and 2107 residents in the Modena area who accessed testing through self-referral. Results: The authors found the overall seroprevalence to be 4.7\% (95\% confidence interval [CI] 4.2-5.2\%), which was higher in women (5.4\%, 95\% CI: 4.5-6.2\%) than in men (4.3\%, 95\% CI: $3.7-4.9 \%)$, and in the oldest age groups (7.3\%, 95\% CI: 5.2-9.3\% for persons aged $60-69$ years, and $11.8 \%, 95 \%$ CI: $8.6-15.1 \%$, for persons aged $\geq 70$ years). Among the occupational categories, the highest seroprevalence was found in healthcare workers (8.8\%, 95\% CI: 7.0-10.5\%), dealers and vehicle repairers (5.2\%, 95\% CI: 2.9-7.6\%), and workers in the sports sector (4.0\%, 95\% CI: 1.8-6.1\%), while there was little or no such evidence for those employed in sectors such as transport and storage, accommodation and restaurant services, and the school system. Conclusions: These results have allowed, for the first time, to assess population seroprevalence in this area of Italy severely hit by the epidemic, while at the same time identifying the subgroups at a higher risk of exposure to SARS-CoV-2. Int J Occup Med Environ Health. 2022;35(1):63-74
\end{abstract}

Key words:

health personnel, SARS-CoV-2, COVID-19, SARS-CoV-2 serological testing, seroepidemiologic studies, occupational groups

\section{INTRODUCTION}

The severe acute respiratory syndrome due to coronavirus 2 (SARS-CoV-2), named COVID-19, was declared a pandemic by the World Health Organization (WHO) on March 11, 2020. This is a novel and extremely seri- ous health condition. The SARS-CoV-2 infection swept across the entire world: by December 2020, it had caused more than 79 million infection cases and 1.7 million related deaths according to WHO. Currently, there are no drug treatments that have proven fully effective [1], but

Funding: this work was supported by the University of Modena and Reggio Emilia (grant entitled "UNIMORE FAR Interdisciplinare Linea FOMO - Fondazione Cassa di Risparmio di Modena 2019," project manager: Prof. Marco Vinceti) and by the University of Modena and Reggio Emilia (grant entitled "UNIMORE FAR Interdisciplinare Linea FOMO - Fondazione Cassa di Risparmio di Modena 2020," project manager: Prof. Annalisa Bargellini).

${ }^{*}$ Contributed equally as senior authors.

Received: January 13, 2021. Accepted: May 19, 2021.

Corresponding author: Marco Vinceti, University of Modena and Reggio Emilia, Department of Biomedical, Metabolic and Neural Sciences, Via Campi 287, 41125 Modena, Italy (e-mail: marco.vinceti@unimore.it). 
the upcoming vaccines should guarantee population coverage [2] although only when herd immunity is established [3].

In Italy, the first nation to be severely hit by this infection, the epidemic was first recognized on February 21, 2020 [4]. The first wave mainly affected Northern Italy [5], with a rapid rise in the number of cases and the peak on March 21, 2020 (657 cases), followed by a decline and stabilization of cases below 600 in June and July 2020 [6]. The reduction in case numbers in Italy, as well as in other countries, was possible thanks to tight mobility restrictions (the lockdown) imposed by the government, combined with testing and tracing measures implemented by public hygiene departments [4,7] and other infection containment measures such as the use of face masks and personal hygiene measures [8]. As for most European countries, Italy witnessed the second wave of the pandemic in autumn 2020, and it was still affected in early 2021 [6]. The factors affecting the uneven distribution across the territory of many countries are partially unknown, although they are likely to encompass environmental factors [9-11] as well as genetic determinants [12].

The SARS-CoV-2 infection, either in symptomatic individuals or in those asymptomatic for COVID-19, is identified following diagnostic molecular RT-PCR tests based on swabs, recognizing the infection status through viral RNA detection. The implementation of these molecular tests at the population level has largely depended on public health policies, the availability of analytical facilities and reagents over space and time, the willingness of individuals to participate and mandatory rules applying, among others, to those entering the country or admitted to some working environments [13]. Therefore, molecular testing results cannot adequately reflect the total number of infected individuals over time and in different areas, apart from small communities characterized by extensive testing such as the small Italian community of Vo' in the Veneto region [14]. This is particularly true for the initial period of the first wave of the epidemic, when the number of diagnostic tests performed was low [5].

For these reasons, assessing the seroprevalence of antiSARS-CoV-2 antibodies could be very informative in light of the expected large number of SARS-CoV-2 infections being mainly undetected due to the absence or paucity of clinical symptoms. Seroprevalence estimates may also allow for identifying the population groups at the greatest risk of developing COVID-19, including ageand sex-specific groups, and occupational categories. A number of studies have assessed seroprevalence within specific communities all over the world, but this has generally involved small population samples and specific categories [15-17].

The purpose of the present study was to evaluate the prevalence of serum-specific antibodies against SARS-CoV-2 in subjects living in the central-western part of the Emilia Romagna region. In particular, the authors aimed to explore the extent of asymptomatic or pauci-symptomatic infections by identifying the percentage of previously infected individuals. The second aim was to determine which characteristics of the study population could have favored the development of the SARS-CoV-2 infection.

\section{MATERIAL AND METHODS}

\section{Study population}

The authors carried out a cross-sectional study in a population of the Emilia Romagna region, Northern Italy. Starting from April 2020, a few private laboratory facilities were authorized by the Emilia Romagna local authorities to carry out serological tests pursuant to regional legislation (DGR350 of April 16, 2020 "COVID19: Discipline of serological tests"). Among the first 8 laboratories to be accredited on the regional level was the Test Laboratory of Modena, a province located in the central-western part of the region (Decree PG/2020/0307727 of April 22, 2020). Following the approval by the "Area Vasta Emilia Nord" Ethics Committee (No. 24690/20), the authors col- 
lected all analytical data available to the Test Laboratory following the implementation of serological tests to detect serum SARS-CoV-2 antibodies in workers and private individuals admitted to the facility in June 1-September 25, 2020, most of whom residing in the Modena province. The workers were referred by their companies, which strongly recommended that their employees be tested. The remaining individuals were admitted to the facility through self-referral, and were not asked to report the reasons for which they sought testing.

\section{Laboratory analysis}

The Test Laboratory determined the serum prevalence of SARS-CoV-2 antibody positivity in the study participants using either quantitative or qualitative tests. Depending on the participants' original request, both quantitative and qualitative tests could be carried out on these samples. After receiving written consent, the Laboratory drew $5 \mathrm{ml}$ of venous blood (for quantitative tests) or a drop of peripheral blood (for qualitative tests) from the study participants. As far as the quantitative analysis was concerned, the Laboratory used 2 different sets of tests. The first was the ELISA anti-SARS-CoV-2 test kit for IgA and IgG from EUROIMMUN ${ }^{\circledR}$ (PerkinElmer, Inc., Waltham, MA, USA), with $100 \%$ sensitivity 10 days after the symptoms onset and $92.5 \%$ specificity. The second was the Elecsys ${ }^{\circledR}$ Anti-SARS-CoV-2 test kit for IgG and IgM (Roche Diagnostics, Risch-Rotkreuz, Swiss), with 100\% sensitivity 14 days after the symptoms onset and $99.8 \%$ specificity. Until August 16, 2020, IgA and IgG had been tested, while from August 17, 2020, IgG and IgM were tested. As for the qualitative analysis, the $\mathrm{KHB}^{\circledR}$ diagnostic kit for SARS-CoV-2 IgM/IgG antibody Colloidal Gold was used, with $98.81 \%$ sensitivity and $98.02 \%$ specificity.

\section{Data analysis}

The authors computed the absolute and relative (\%) prevalence of serum antibodies against SARS-CoV-2 in the whole study population and in selected subgroups. In data analysis and interpretation, they preferred to focus on the strength and the statistical precision of the point estimates, instead of relying on statistical significance testing and p-value cutpoints [18-20]. They provided $95 \% \mathrm{CI}$ for the distributions of anti-SARS-CoV-2 antibody positive tests in the whole study population and its subgroups.

In particular, for occupational categories, the authors divided the participating workers into 12 wide categories according to 2007 Ateco (economic activity classification, Ateco 2007 - ISTAT). For the purpose of the study, the highest level of aggregation of Ateco activities (the "section" level) was considered. Activities involving mostly sedentary and office work (Ateco sections J, K, $\mathrm{M}, \mathrm{N}$ ) were merged into a single category. With regard to section R: "Artistic, sports, entertainment and fun activities," of the 327 subjects only 1 (negative at the serological test) belonged to the sub-category of "other activities connected with lotteries and betting" while the remaining 326 people belonged to the world of sport (i.e., to the classes, categories and sub-categories marked as "sports club activities," "sports bodies and organizations, promotion of sporting events," "sports association"); henceforth, they are referred to as "workers in the sports sector." Microsoft Excel v. 16 (Microsoft Office 2019) and Stata software v. 16.1 (2021 - Stata Corp., College Station, TX) were used for data collection and analysis.

\section{RESULTS}

In the study period, 7752 individuals were admitted to the laboratory facility to be tested for the presence of antibodies against SARS-CoV-2 (Figure 1). Of these, 596 subjects took the test more than once. In such cases, only the most recent result was considered. A few records (191) were discarded due to an internal reporting error inherent in the analytical system on September 4, 2020. Table 1 reports the characteristics of the 7561 study participants: 


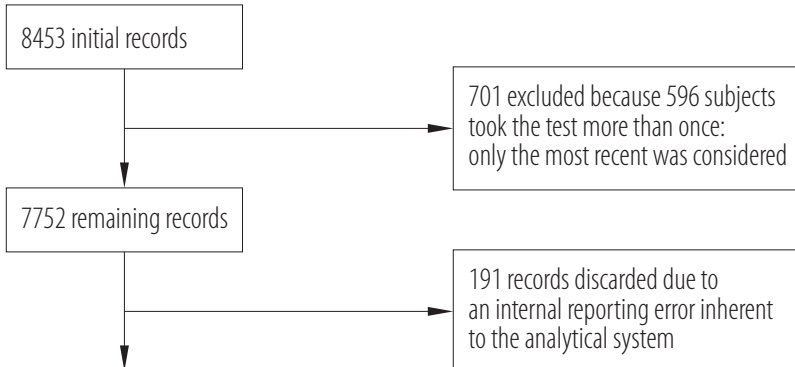

7561 final records included in the study

Figure 1. Flow-chart with a selection of the participants of the serum anti-SARS-CoV-2 antibody prevalence study, June 1-September 25, 2020, Modena, Northern Italy

4683 (61.9\%) were men and 2878 (38.1\%) women, with the overall age $(\mathrm{M} \pm \mathrm{SD}) 44 \pm 14$ years. Division by province of residence indicates that they were from:

- Modena - 5634 (74.5\%),

- Reggio Emilia - 296 (3.9\%),

- Parma - 212 (2.8\%),

- Bologna - 27 (0.4\%),

- other provinces -1392 (18.4\%).

A stratified analysis by sex showed a similar distribution of both age and the province of residence. The majority of the participants were workers, and the distribution by occupational sector showed that they represented mainly "manufacturing activities" (32.8\%), "information and communication services/financial and insurance activities; etc." (31.5\%), and "health sector" (18.0\%), this latter with a higher number of female participants (31.9\%) compared to male participants (11.5\%).

The total number of positive participants, i.e., those with a positive test for serum anti-SARS-CoV-2 antibodies, regardless of the type of the test performed and the detected Ig, amounted to 354 (4.7\%, 95\% CI: 4.2-5.2\%), while 7207 (95.3\%) participants were negative (Table 2). The prevalence rates of positivity depending on the province of residence were:

- 4.4\% (95\% CI: 3.9-4.9\%) for Modena (248/5634 positive subjects),
- 7.8\% (95\% CI: 4.7-10.8\%) for Reggio Emilia (23/296 positive subjects),

- 18.9\% (95\% CI: 13.6-24.2\%) for Parma (40/212 positive subjects),

- 7.4\% (95\% CI: 0.0-18.0\%) for Bologna (2/27 positive subjects).

Overall, women showed slightly higher seroprevalence rates than men (5.4\%, $95 \%$ CI: $4.5-6.2 \%$ vs. $4.3 \%, 95 \%$ CI: $3.7-4.9 \%)$. The participants' age was higher in the seropositive subjects (48.3 years, 95\% CI: $46.6-50.1$ ) than in the negative ones (43.6 years, 95\%CI: 43.3-43.9). The highest seroprevalence emerged in the 2 oldest age groups: those aged $\geq 70$ years showed $11.8 \%$ (95\% CI: 8.6-15.1\%) of anti-SARS-CoV-2 antibody seroprevalence; and those aged $60-69$ years $7.3 \%$ (95\% CI: 5.3-9.3\%) seroprevalence. The quantitative test was undergone by 5347 participants, while the rapid qualitative test was performed on 2214 subjects. Seroprevalence was considerably greater in the first group (5.8\%, 95\% CI: 5.2-6.4\%) compared with the second one (2.0\%, 95\% CI: $1.4-2.6 \%)$.

Considering the quantitative tests, the positivity rates for the immunoglobulin tested were:

- $0.3 \%$ for IgM ( $95 \%$ CI: $0.04-0.6 \%$ with $5 / 1579$ positives),

- $5.1 \%$ for IgG (95\% CI: $4.6-5.7 \%$ with $275 / 5347$ positives)

- 5.6\% for IgA (95\% CI: $4.8-6.4 \%$ with $212 / 3768$ positives).

As regards the qualitative test, the positivity rates for the immunoglobulin tested were:

- $0.9 \%$ for IgM (95\% CI: $0.5-1.2 \%$ with $19 / 2214$ positives),

- $1.4 \%$ for IgG (95\% CI: $0.9-1.8 \%$ with $30 / 2214$ positives).

The number of participants referred by their companies amounted to 5454, while 2107 referred themselves to the laboratory for other unreported reasons. For the self-referred subjects, no information about the oc- 
Table 1. Characteristics of 7561 study participants recruited in the period of June 1-September 25, 2020, at the Test Laboratory in Modena, Italy

\begin{tabular}{|c|c|c|c|}
\hline \multirow[b]{2}{*}{ Variable } & \multicolumn{3}{|c|}{$\begin{array}{l}\text { Participants } \\
(\mathrm{N}=7561)\end{array}$} \\
\hline & total & $\begin{array}{c}\text { men } \\
(\mathrm{N}=4683 \\
61.9 \%)\end{array}$ & $\begin{array}{c}\text { women } \\
(\mathrm{N}=2878, \\
38.1 \%)\end{array}$ \\
\hline Age [years] $(\mathrm{M} \pm \mathrm{SD})$ & $44 \pm 14$ & $43 \pm 14$ & $45 \pm 15$ \\
\hline$<65$ years $[\mathrm{n}(\%)]$ & $6932(91.7)$ & $4356(93.0)$ & $2576(89.5)$ \\
\hline$\geq 65$ years $[n(\%)]$ & $629(8.3)$ & $327(7.0)$ & $302(10.5)$ \\
\hline \multicolumn{4}{|l|}{ Province of residence [n (\%)] } \\
\hline Modena & $5634(74.5)$ & $3491(74.5)$ & $2143(74.5)$ \\
\hline Reggio Emilia & $296(3.9)$ & $136(2.9)$ & $160(5.6)$ \\
\hline Parma & $212(2.8)$ & $98(2.1)$ & $114(4.0)$ \\
\hline Bologna & $27(0.4)$ & $14(0.3)$ & $13(0.4)$ \\
\hline other/missing data & $1392(18.4)$ & $944(20.2)$ & $448(15.6)$ \\
\hline \multicolumn{4}{|l|}{ Referral category [n (\%)] } \\
\hline private & $2107(27.9)$ & $957(20.4)$ & $1150(40.0)$ \\
\hline workers & $5454(72.1)$ & $3726(79.6)$ & $1728(60.0)$ \\
\hline \multicolumn{4}{|l|}{ Occupational sector (workers only) ${ }^{\mathrm{a}}[\mathrm{n}(\%)]$} \\
\hline agriculture, forestry and fishing (A) & $3(0.1)$ & $3(0.1)$ & $0(0.0)$ \\
\hline manufacturing activities (C) & $1788(32.8)$ & $1436(38.5)$ & $352(20.3)$ \\
\hline water supply; sewer networks, waste management and remediation activities $(\mathrm{E})$ & $85(1.6)$ & $65(1.7)$ & $20(1.2)$ \\
\hline constructions (F) & $26(0.5)$ & $22(0.6)$ & $4(0.2)$ \\
\hline wholesale and retail trade; repair of motors vehicles and motorcycles $(G)$ & $362(6.6)$ & $240(6.4)$ & $122(7.1)$ \\
\hline transport and storage $(\mathrm{H})$ & $102(1.9)$ & $59(1.6)$ & $43(2.5)$ \\
\hline activities of the accommodation and restaurant services (I) & $13(0.2)$ & $6(0.2)$ & $7(0.4)$ \\
\hline $\begin{array}{l}\text { information and communication services; financial and insurance activities; professional } \\
\text { scientific and technical activities; rental, travel agencies, business support services (J,K, M, N) }\end{array}$ & $1720(31.5)$ & $1168(31.3)$ & $552(31.9)$ \\
\hline education (P) & $26(0.5)$ & $9(0.2)$ & $17(1.0)$ \\
\hline health sector (Q) & $982(18.0)$ & $430(11.5)$ & $552(31.9)$ \\
\hline workers in the sports sector (R) & $327(6.0)$ & $275(7.4)$ & $52(3.0)$ \\
\hline other service activities (S) & $8(0.1)$ & $6(0.2)$ & $2(0.1)$ \\
\hline missing & $12(0.2)$ & $7(0.2)$ & $5(0.3)$ \\
\hline
\end{tabular}

${ }^{a}$ The letters indicate Ateco classification occupational categories.

cupational status was made available. Of a total of 5454 workers, it was not possible to retrieve the Ateco code for 12 , and they were excluded from further analyses. The results for the 5442 remaining employees are pre- sented in Table 3. The group with the greatest prevalence of seropositivity was that of healthcare workers (8.8\%, 95\% CI: $7.0-10.5 \%$ of the entire category), followed by dealers and vehicle repairers (5.2\%, 95\% CI: 
Table 2. Anti-SARS-CoV-2 antibody positive (Ab+) tests in the period of June 1-September 25, 2020, at the Test Laboratory in Modena, Italy

\begin{tabular}{|c|c|c|c|c|c|c|}
\hline \multirow{3}{*}{ Variable } & \multicolumn{6}{|c|}{$\begin{array}{c}\text { Participants } \\
(\mathrm{N}=7561) \\
{[\mathrm{n}(\%)]}\end{array}$} \\
\hline & \multicolumn{2}{|c|}{ total } & \multicolumn{2}{|c|}{$\begin{array}{c}\text { men } \\
(\mathrm{N}=4683,61.9 \%)\end{array}$} & \multicolumn{2}{|c|}{$\begin{array}{c}\text { women } \\
(\mathrm{N}=2878,38.1 \%)\end{array}$} \\
\hline & total test & $\begin{array}{c}\text { SARS-CoV-2 } \\
\text { Ab+ test } \\
(\mathrm{N}=354,4.7 \%)\end{array}$ & total test & $\begin{array}{c}\text { SARS-CoV-2 } \\
\text { Ab+ test } \\
(\mathrm{N}=200,4.3 \%)\end{array}$ & total test & $\begin{array}{c}\text { SARS-CoV-2 } \\
\text { Ab+ test } \\
(\mathrm{N}=154,5.4 \%)\end{array}$ \\
\hline \multicolumn{7}{|l|}{ Age } \\
\hline$<20$ years & $248(3.3)$ & $12(4.8)$ & $133(2.8)$ & $7(5.3)$ & $115(4.0)$ & $5(4.4)$ \\
\hline $20-29$ years & $1229(16.3)$ & $46(3.7)$ & $841(18.0)$ & $32(3.8)$ & $388(13.5)$ & $14(3.6)$ \\
\hline $30-39$ years & 1505 (19.9) & $56(3.7)$ & $953(20.4)$ & $31(3.3)$ & $552(19.2)$ & $25(4.6)$ \\
\hline $40-49$ years & $1915(25.3)$ & $70(3.7)$ & $1169(25.0)$ & $35(3.0)$ & $746(25.9)$ & $35(4.7)$ \\
\hline $50-59$ years & $1641(21.7)$ & $78(4.8)$ & $1027(21.9)$ & $46(4.5)$ & $614(21.3)$ & $32(5.2)$ \\
\hline $60-69$ years & $643(8.6)$ & $47(7.3)$ & $362(7.7)$ & $25(6.9)$ & $281(9.8)$ & $22(7.8)$ \\
\hline$\geq 70$ years & $380(5.0)$ & 45 (11.8) & $198(4.2)$ & 24 (12.1) & $182(6.3)$ & $21(11.6)$ \\
\hline \multicolumn{7}{|l|}{ Test type } \\
\hline quantitative & 5347 (70.7) & $309(5.8)$ & 3199 (68.3) & $171(5.3)$ & $2148(74.6)$ & $138(6.4)$ \\
\hline qualitative & $2214(29.3)$ & $45(2.0)$ & 1484 (31.7) & $29(2.0)$ & $730(25.4)$ & $16(2.2)$ \\
\hline \multicolumn{7}{|c|}{ Antibody/lg tested } \\
\hline $\lg A$ & 3768 & $212(5.6)$ & 2205 & $112(5.1)$ & 1563 & $100(6.4)$ \\
\hline $\lg G$ & 7561 & $305(4.0)$ & 4683 & $169(3.6)$ & 2878 & $136(4.7)$ \\
\hline $\lg M$ & 3793 & $24(0.6)$ & 2478 & $16(0.6)$ & 1315 & $8(0.6)$ \\
\hline \multicolumn{7}{|l|}{ Referral category } \\
\hline private & 2107 (27.9) & $140(6.6)$ & $957(20.4)$ & $67(7.0)$ & $1150(40.0)$ & $73(6.3)$ \\
\hline workers & 5454 (72.1) & $214(3.9)$ & $3726(79.6)$ & $133(3.6)$ & $1728(60.0)$ & $81(4.7)$ \\
\hline
\end{tabular}

2.9-7.6\%), and workers in the sports sector $(4.0 \%, 95 \% \mathrm{CI}$ :

$1.8-6.1 \%)$. Very limited or no antibody seroprevalence emerged in sectors such as "constructions," "transport and storage," "activities of the accommodation and restaurant services," and "education." In the category of "manufacturing activities," the authors also investigated the seroprevalence of the subgroup of "production of meat products (including poultry meat)": of a total of 14 subjects belonging to this class, none was tested positive. A graphic representation of these results can be seen in Figure 2.

\section{DISCUSSION}

The survey has shown that in this population severely hit by the epidemic the percentage of subjects who got infected was close to $5 \%$. This approaches $6 \%$ when considering only the subjects undergoing the quantitative serological tests, and it drops to $2 \%$ when considering only subjects taking the qualitative (rapid) tests considered less reliable. These variations may be due to the different intrinsic characteristics of the tests, but also to the preferred use of quantitative serological tests in the case of suspected infections. 
Table 3. Anti-SARS-CoV-2 antibody (Ab) status and percentage of antibody positivity by occupational category (Ateco code) in workers in the period of June 1-September 25, 2020, at the Test Laboratory in Modena, Italy

\begin{tabular}{|c|c|c|c|c|c|c|}
\hline \multirow{3}{*}{ Occupational category ${ }^{\mathrm{a}}$} & \multicolumn{6}{|c|}{$\begin{array}{l}\text { Participants } \\
(\mathrm{N}=7561)\end{array}$} \\
\hline & \multicolumn{2}{|c|}{$\begin{array}{c}\text { total } \\
(\mathrm{N}=5442)\end{array}$} & \multicolumn{2}{|l|}{$\begin{array}{c}\text { men } \\
(N=3719)\end{array}$} & \multicolumn{2}{|l|}{$\begin{array}{l}\text { women } \\
(\mathrm{N}=1723)\end{array}$} \\
\hline & $\begin{array}{l}\text { Ab+/total test } \\
\quad[\mathrm{n} / \mathrm{n}]\end{array}$ & $\begin{array}{c}\mathrm{Ab+} \\
{[\%]}\end{array}$ & $\begin{array}{c}\text { Ab+/total test } \\
\quad[n / n]\end{array}$ & $\begin{array}{l}\mathrm{Ab+} \\
{[\%]}\end{array}$ & $\begin{array}{l}\text { Ab+/total test } \\
\quad[\mathrm{n} / \mathrm{n}]\end{array}$ & $\begin{array}{l}\mathrm{Ab+} \\
{[\%]}\end{array}$ \\
\hline Agriculture, forestry and fishing $(A)$ & $0 / 0$ & 3 & $0 / 3$ & 0.0 & - & - \\
\hline Manufacturing activities (C) & $36 / 1788$ & 2.0 & $30 / 1436$ & 2.1 & $6 / 352$ & 1.7 \\
\hline $\begin{array}{l}\text { Water supply; sewer networks, waste management and remediation } \\
\text { activities (E) }\end{array}$ & $2 / 85$ & 2.4 & $2 / 65$ & 3.1 & $0 / 20$ & 0.0 \\
\hline Constructions (F) & $0 / 26$ & 0.0 & $0 / 22$ & 0.0 & $0 / 4$ & 0.0 \\
\hline Wholesale and retail trade; repair of motors vehicles and motorcycles (G) & $19 / 362$ & 5.2 & $13 / 240$ & 5.4 & $6 / 122$ & 4.9 \\
\hline Transport and storage (H) & $1 / 102$ & 1.0 & $0 / 59$ & 0.0 & $1 / 43$ & 2.3 \\
\hline Activities of the accommodation and restaurant services (I) & $0 / 13$ & 0.0 & $0 / 6$ & 0.0 & $0 / 7$ & 0. \\
\hline $\begin{array}{l}\text { Information and communication services; financial and insurance activities; } \\
\text { professional scientific and technical activities; rental, travel agencies, } \\
\text { business support services (J,K, M, N) }\end{array}$ & $57 / 1720$ & 3.3 & $40 / 1168$ & 3.4 & $17 / 552$ & 3.1 \\
\hline Education (P) & $0 / 26$ & 0.0 & $0 / 9$ & 0.0 & $0 / 17$ & 0.0 \\
\hline Health sector (Q) & $86 / 982$ & 8.8 & $37 / 430$ & 8.6 & $49 / 552$ & 8.9 \\
\hline Workers in the sports sector (R) & $13 / 327$ & 4.0 & $11 / 275$ & 4.0 & $2 / 52$ & 3.8 \\
\hline Other service activities (S) & $0 / 8$ & 0.0 & $0 / 6$ & 0.0 & $0 / 2$ & 0.0 \\
\hline
\end{tabular}

${ }^{a}$ The letters indicate Ateco classification occupational categories.

Focusing only on IgG of the few subjects who took the quantitative serological tests, seroprevalence accounted for $5.1 \%$. The figure differs from the results obtained through the Italian national seroprevalence SARS-CoV-2 antibody survey carried out on May 25-July 15, 2020, by the Ministry of Health and the National Institute of Statistics [21]. The survey based on quantitative tests found IgG positivity to be $2.5 \%$ in the whole country and $2.8 \%$ in the Emilia Romagna region only. However, no estimate for the Modena province is available from the national survey. The representativeness and composition of the investigated population were different in the 2 studies as was their timing, thus hampering any meaningful comparison. Other studies carried out in Italy have identified higher seroprevalence, especially in other areas of the North severely affected by the pandemic $[16,22,23]$.

The authors found a higher percentage of positive females than males, consistent with other studies. In females, however, mortality rates were lower than in males $[17,24]$. This may be linked to a number of factors: first of all, a greater susceptibility to infections among females (despite greater resistance); secondly, lower COVID-19 lethality in females compared to males; and thirdly, familial and social roles of women increasing their risk of contracting the virus.

In addition, the authors found a steep increase in seroprevalence in older age groups, since people aged $60-69$ years and $\geq 70$ years showed the highest prevalence 


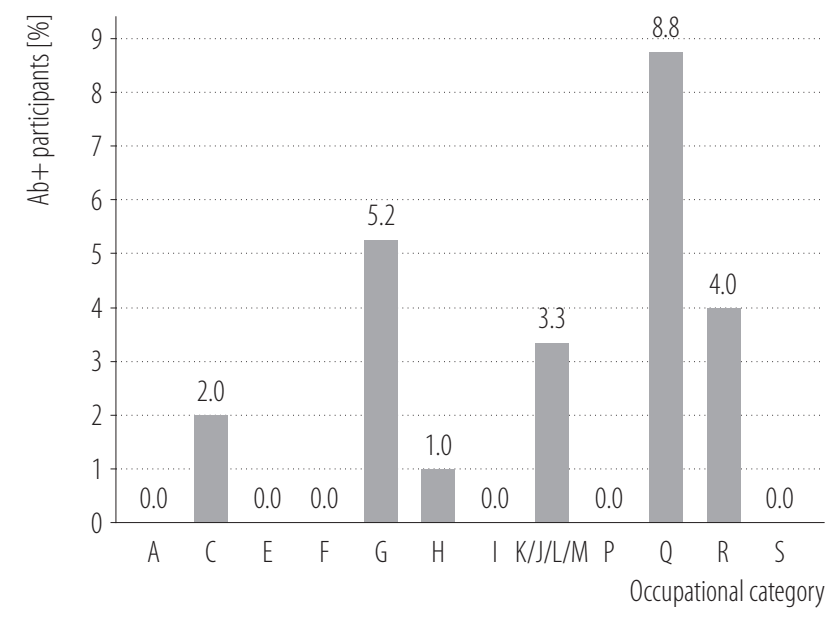

The letters indicate Ateco classification occupational categories as reported in Table 1.

Figure 2. Subjects with anti-SARS-CoV-2 antibody positive $(\mathrm{Ab}+)$ tests by occupational category, June 1-September 25, 2020, Modena, Northern Italy

( $7.3 \%$ and $11.8 \%$, respectively). The importance of this finding should be evaluated in light of the fact that these age groups have been indicated as displaying the highest COVID-19 mortality by the Italian National Institute of Health [6]. In addition, the excess seroprevalence found in these age groups may still be somehow underestimating the real figures, because the death toll was the highest in these 2 age categories in Modena, as everywhere else. The present age-specific findings are in contrast with those from the only national seroprevalence survey carried out so far, in which the age group with the highest percentage of seropositive individuals was reported to be that of 50-59 years [21]. This may be due to some differences in terms of the period in which the seroprevalence survey was carried out, with this study having been completed more recently. In turn, this raises a number of relevant issues, from the continuous and increasing exposure to the virus in the late spring and summer, when the lockdown was lifted and mobility restrictions eased, to other characteristics of the 2 surveys concerning the representativeness of the underlying resident population.

As far as the occupational risk factors of the infection were concerned, not surprisingly, healthcare workers were the most exposed to SARS-CoV-2, followed by dealers, vehicle repairers and sportsmen. Similarly high seroprevalence of anti-SARS-CoV-2 antibodies in healthcare workers had already been identified, particularly in the areas of Northern Italy heavily affected by the pandemic $[15,25,26]$, with a corresponding value in the national survey of 5.3\% [21]. This clearly highlights the high infection risk experienced by this crucial sector and the importance of increasing their protection towards SARS-CoV-2 contact. Unfortunately, there are limited data on occupational groups other than healthcare workers that may have undergone excess risks of SARS-CoV-2 infection.

In their study, the authors found, on the one hand, that workers heavily involved in direct contact with such subjects as clients, patients and sports opponents had a higher seroprevalence of anti-SARS-CoV-2 antibodies. On the other hand, no excess seropositivity emerged for office workers with no contact with the public (as might be expected), for workers from the manufacturing and construction sectors, and for employees in transportation and storage. This indicates that, so far, these sectors have enforced enough physical distancing to mitigate the risk of airborne disease transmission from COVID-19. Interestingly, no increased risk was found for workers in the education sector. In this case, however, the result was not unexpected by virtue of the limited mobility and remote work of employees during the national lockdown.

Excess seroprevalence of anti-SARS-CoV-2 antibodies emerged in the occupational groups of workers in the sports sector, including categories such as sportsmen. This is an interesting finding that allows for assessing the potential risk of close contacts during contact sports, as well as a higher risk of airborne viral transmission arising in such circumstances [27]. Although these estimates were based on a very limited sample size, and notwithstanding little evidence available from the literature, these data suggest the need to further investigate the safety of team and community sports practice during the current pandemic. 
Interestingly, the subgroup of "production of meat products (including poultry meat)" did not show any positivity to the serological test, an interesting finding - despite its small sample size - given the recent occurrence of small outbreaks in slaughterhouses or similar facilities [28,29]. The seroprevalence found in the study participants may have slightly underestimated the real incidence of the SARS-CoV-2 infection in the period considered. In fact, it has been suggested that anti-SARS-CoV-2 antibody seroprevalence decreases over time, particularly in the case of asymptomatic infections [30]. However, recent data have not supported such a substantial decrease [31,32]. In addition, even assuming such a decrease, a few months should elapse from the infection to make it relevant, while the study population was tested close to the possible antecedent infection.

An assessment of seroprevalence may also enable estimating the COVID-19 infection fatality rate in the study area, moving beyond the case-fatality rate. In particular, the former estimate can be expected to be clearly lower than the latter, given the higher number of infected subjects emerging from seroprevalence surveys compared with molecular testing detection [21,33]. However, considering the large number of deaths from COVID-19 in the Modena population, as well as in several Northern Italy provinces, during the first wave of the pandemic $[10,34]$, and the comparison with other airborne viral diseases, there appears to be no doubt about the very high severity of COVID-19 in this community, particularly in selected population subgroups. Finally, despite the limited seroprevalence rate in the study population, the recently published nationwide findings suggest that even a small amount of humoral immunity may hamper subsequent waves of the disease [33].

Some limitations of this study must be outlined. The authors were unable to collect detailed information about the relevant characteristics of SARS-CoV-2 infection, such as whether the participants were asymptomatic or already presented signs and symptoms of COVID-19. For the latter, they were also unable to assess differences in disease severity, a factor that may have affected the extent and duration of the immune response against SARSCoV-2 [35]. However, since all subjects were recruited within 7 months from the beginning of the pandemic, antibodies to SARS-CoV-2 levels should not have been waned but remained detectable, as also confirmed by a recent Chinese study showing that they persisted for at least 9 months [35]. In addition, the sample size was not enough to carry out a stratified analysis for some occupational groups with low numbers of employees, which affected in some subgroups the statistical precision of the estimates.

This study also has some strengths. To the best of the authors' knowledge, this is the first available study providing seroprevalence data in the Northern Italy population mirroring SARS-CoV-2 infections during the first wave. The size of the overall study population was large, and many specific occupational activities were represented, also given the highly industrialized pattern of the population of the study region. Finally, the detailed information made available about the occupational status of the study participants provided some helpful insights about the workers who experienced a higher burden of the disease and, therefore, were at a higher risk of virus transmission in their occupational environment.

\section{CONCLUSIONS}

Overall, this study provided, for the first time, an assessment of population seroprevalence in the Northern Italy population severely hit by the epidemic, with a higher value when quantitative serological tests were performed, but a lower percentage when considering the less reliable rapid tests. Finally, these findings suggest that occupational subgroups at a higher risk of exposure to SARS$\mathrm{CoV}-2$ were healthcare workers, dealers and vehicle repairers, and workers in the sports sector. 


\section{ACKNOWLEDGMENTS}

The authors would like to express their gratitude to all the subjects for participating in this study.

\section{REFERENCES}

1. CORIST. CORVID-19 RISK and Treatments (CORIST) Collaboration. Use of hydroxychloroquine in hospitalised COVID-19 patients is associated with reduced mortality: Findings from the observational multicentre Italian CORIST study. Eur J Intern Med. 2020;82:38-47, https://doi.org/10.1016/j.ejim. 2020.08.019.

2. Calina D, Docea AO, Petrakis D, Egorov AM, Ishmukhametov AA, Gabibov AG, et al. Towards effective COVID19 vaccines: Updates, perspectives and challenges (Review). Int J Mol Med. 2020;46(1):3-16, https://doi.org/10.3892/ijmm. 2020.4596.

3. Frederiksen LSF, Zhang Y, Foged C, Thakur A. The long road toward COVID-19 herd immunity: Vaccine platform technologies and mass immunization strategies. Front Immunol. 2020;11:1817, https://doi.org/10.3389/fimmu.2020.01817.

4. Vinceti M, Filippini T, Rothman KJ, Ferrari F, Goffi A, Maffeis $\mathrm{G}$, et al. Lockdown timing and efficacy in controlling COVID-19 using mobile phone tracking. EClinicalMedicine. 2020;25:100457, https://doi.org/10.1016/j.eclinm.2020. 100457.

5. Onder G, Rezza G, Brusaferro S. Case-fatality rate and characteristics of patients dying in relation to COVID-19 in Italy. JAMA. 2020;323(18):1775-6, https://doi.org/10.1001/jama. 2020.4683

6. Italian Civil Protection Department [Internet]. Rome: Protezione Civile; 2021 [cited 2021 Feb 28]. Available from: https://github.com/pcm-dpc/COVID-19.

7. Hellewell J, Abbott S, Gimma A, Bosse NI, Jarvis CI, Russell TW, et al. Feasibility of controlling COVID-19 outbreaks by isolation of cases and contacts. Lancet Glob Health. 2020;8(4): e488-96, https://doi.org/10.1016/S2214-109X(20)30074-7.

8. West R, Michie S, Rubin GJ, Amlot R. Applying principles of behaviour change to reduce SARS-CoV-2 transmission. Nat
Hum Behav. 2020;4(5):451-9, https://doi.org/10.1038/s415 62-020-0887-9.

9. Copat C, Cristaldi A, Fiore M, Grasso A, Zuccarello P, Signorelli SS, et al. The role of air pollution (PM and NO2) in COVID-19 spread and lethality: A systematic review. Environ Res. 2020;191:110129, https://doi.org/10.1016/j.envres. 2020.110129 .

10. Filippini T, Rothman KJ, Cocchio S, Narne E, Mantoan D, Saia M, et al. Associations between mortality from COVID-19 in two Italian regions and outdoor air pollution as assessed through tropospheric nitrogen dioxide. Sci Total Environ. 2021;760:143355, https://doi.org/10.1016/j.scito tenv.2020.143355.

11. Filippini T, Rothman KJ, Goffi A, Ferrari F, Maffeis G, Orsini N, et al. Satellite-detected tropospheric nitrogen dioxide and spread of SARS-CoV-2 infection in Northern Italy. Sci Total Environ. 2020;739:140278, https://doi.org/10.1016/ j.scitotenv.2020.140278.

12. Ovsyannikova IG, Haralambieva IH, Crooke SN, Poland GA, Kennedy RB. The role of host genetics in the immune response to SARS-CoV-2 and COVID-19 susceptibility and severity. Immunol Rev. 2020;296(1):205-19, https://doi. org/10.1111/imr.12897.

13. Rhoads DD, Cherian SS, Roman K, Stempak LM, Schmotzer CL, Sadri N. Comparison of Abbott ID Now, DiaSorin Simplexa, and CDC FDA emergency use authorization methods for the detection of SARS-CoV-2 from nasopharyngeal and nasal swabs from individuals diagnosed with COVID-19. J Clin Microbiol. 2020;58(8):e00760-20, https:// doi.org/10.1128/JCM.00760-20.

14. Lavezzo E, Franchin E, Ciavarella C, Cuomo-Dannenburg G, Barzon L, Del Vecchio C, et al. Suppression of a SARSCoV-2 outbreak in the Italian municipality of Vo'. Nature. 2020;584(7821):425-9, https://doi.org/10.1038/s41586-0202488-1.

15. Sotgiu G, Barassi A, Miozzo M, Saderi L, Piana A, Orfeo N, et al. SARS-CoV-2 specific serological pattern in healthcare workers of an Italian COVID-19 forefront hospital. 
BMC Pulm Med. 2020;20(1):203, https://doi.org/10.1186/ s12890-020-01237-0.

16. Percivalle E, Cambie G, Cassaniti I, Nepita EV, Maserati R, Ferrari A, et al. Prevalence of SARS-CoV-2 specific neutralising antibodies in blood donors from the Lodi Red Zone in Lombardy, Italy, as at 06 April 2020. Euro Surveill. 2020;25(24):2001031, https://doi.org/10.2807/1560-7917.ES. 2020.25.24.2001031.

17. Fiore JR, Centra M, De Carlo A, Granato T, Rosa A, Sarno M, et al. Results from a survey in healthy blood donors in South Eastern Italy indicate that we are far away from herd immunity to SARS-CoV-2. J Med Virol. 2020;93(3):1739-42, https://doi.org/10.1002/jmv.26425.

18. Rothman KJ. Disengaging from statistical significance. Eur J Epidemiol. 2016;31(5):443-4, https://doi.org/10.1007/s10654016-0158-2.

19. Amrhein V, Greenland S, McShane B. Scientists rise up against statistical significance. Nature. 2019;567(7748): 305-7, https://doi.org/10.1038/d41586-019-00857-9.

20. Wasserstein RL, Lazar NA. The ASA statement on p-values: Context, process, and purpose. Am Stat. 2016;70(2):129-33, https://doi.org/10.1080/00031305.2016.1154108.

21. National Institute of Statistics [Internet]. Rome: The Institute; 2020 [cited 2021 Mar 24]. [First results of the seroprevalence investigation on SARS-COV-2]. Available from: https://www.istat.it/it/files//2020/08/ReportPrimiRisultatiIndagineSiero.pdf. Italian.

22. Vena A, Berruti M, Adessi A, Blumetti P, Brignole M, Co$\operatorname{lognato} \mathrm{R}$, et al. Prevalence of antibodies to SARS-CoV-2 in Italian adults and associated risk factors. J Clin Med. 2020;9(9):2780, https://doi.org/10.3390/jcm9092780.

23. Pagani G, Conti F, Giacomelli A, Bernacchia D, Rondanin R, Prina A, et al. Seroprevalence of SARS-CoV-2 significantly varies with age: Preliminary results from a mass population screening. J Infect. 2020;81(6):e10-2, https://doi.org/ 10.1016/j.jinf.2020.09.021.

24. Perez-Lopez FR, Tajada M, Saviron-Cornudella R, SanchezPrieto M, Chedraui P, Teran E. Coronavirus disease 2019 and gender-related mortality in European countries: A meta-analysis. Maturitas. 2020;141:59-62, https://doi.org/10. 1016/j.maturitas.2020.06.017.

25. Consonni D, Bordini L, Nava C, Todaro A, Lunghi G, Lombardi A, et al. COVID-19: What happened to the healthcare workers of a research and teaching hospital in Milan, Italy? Acta Biomed. 2020;91(3):e2020016, https:/doi.org/ 10.23750/abm.v91i3.10361.

26. Modenese A, Gobba F. Increased risk of COVID-19-related deaths among general practitioners in Italy. Healthcare (Basel). 2020;8(2):155, https://doi.org/10.3390/healthcare80 20155 .

27. Löllgen H, Bachl N, Papadopoulou T, Shafik A, Holloway G, Vonbank K, et al. Recommendations for return to sport during the SARS-CoV-2 pandemic. BMJ Open SEM. 2020;6(1): e000858, https://doi.org/10.1136/bmjsem-2020-000858.

28. Dyal JW, Grant MP, Broadwater K, Bjork A, Waltenburg MA, Gibbins JD, et al. COVID-19 among workers in meat and poultry processing facilities - 19 States, April 2020. MMWR Morb Mortal Wkly Rep. 2020;69(18):557-61, https:/doi. org/10.15585/mmwr.mm6918e3.

29. Middleton J, Reintjes R, Lopes H. Meat plants-a new front line in the Covid-19 pandemic. BMJ. 2020;370:m2716, https://doi.org/10.1136/bmj.m2716.

30. Long QX, Tang XJ, Shi QL, Li Q, Deng HJ, Yuan J, et al. Clinical and immunological assessment of asymptomatic SARSCoV-2 infections. Nat Med. 2020;26(8):1200-4, https://doi. org/10.1038/s41591-020-0965-6.

31. Wajnberg A, Amanat F, Firpo A, Altman DR, Bailey MJ, Mansour M, et al. Robust neutralizing antibodies to SARSCoV-2 infection persist for months. Science. 2020;370 (6521):1227-30, https://doi.org/10.1126/science.abd7728.

32. Neagu M, Calina D, Docea AO, Constantin C, Filippini T, Vinceti M, et al. Back to basics in COVID-19: Antigens and antibodies-Completing the puzzle. J Cell Mol Med. 2021; 25(10):4523-33, https://doi.org/10.1111/jcmm.16462.

33. Vinceti M, Filippini T, Rothman KJ, Di Federico S, Orsini N. SARS-CoV-2 infection incidence during the first and second 
COVID-19 waves in Italy. Environ Res. 2021;197:111097, https://doi.org/10.1016/j.envres.2021.111097.

34. Di Castelnuovo A, Bonaccio M, Costanzo S, Gialluisi A, Antinori A, Berselli N, et al. Common cardiovascular risk factors and in-hospital mortality in 3,894 patients with COVID-19: survival analysis and machine learning-based findings from the multicentre Italian CORIST Study. Nutr
Metab Cardiovasc Dis. 2020;30(11):1899-913, https://doi. $\operatorname{org} / 10.1016 /$ j.numecd.2020.07.031.

35. He Z, Ren L, Yang J, Guo L, Feng L, Ma C, et al. Seroprevalence and humoral immune durability of anti-SARS-CoV-2 antibodies in Wuhan, China: a longitudinal, population-level, cross-sectional study. Lancet. 2021;397(10279):1075-84, https://doi.org/10.1016/S0140-6736(21)00238-5.

This work is available in Open Access model and licensed under a Creative Commons Attribution-NonCommercial 3.0 Poland License - http://creativecommons.org/ licenses/by-nc/3.0/pl/deed.en. 